Svitlana Kolosok,

Ph.D, Sumy State University, Ukraine

(iD) ORCID ID, 0000-0002-5133-9878

email: kolosok@management.sumdu.edu.ua

Tetyana Pimonenko,

Dr.Sc., Sumy State University, Ukraine

(iD) ORCID ID, 0000-0001-6442-3684

email: tetyana_pimonenko@econ.sumdu.edu.ua

Alona Yevdokymova,

Ph.D., Sumy State University, Ukraine

(iD) ORCID ID, 0000-0001-6456-4436

email: a.yevdokymova@management.sumdu.edu.ua

Nazim Ozbey Hajiyev,

Ph.D., Azerbaijan State University of Economics, Azerbaijan

Harvard University, USA

iD ORCID ID, 0000-0002-3093-2322

email: n.hajiyev@unec.edu.az

Maksym Palienko,

University of Insubria, Italy

email: mpalienko@gmail.com

Lesya Prasol,

Entrepreneur, China

email: lesia_prasol@icloud.com

Correspondence author: kolosok@management.sumdu.edu.ua

\title{
ENERGY EFFICIENCY POLICY: IMPACT OF GREEN INNOVATIONS
}

Abstract. The European energy policy is a core role in the developing of the new model of the energy market and carbon-free economy in Ukraine. In the paper, the authors analysed the key issues on the way to implement the European policy on increasing of energy efficiency and green innovations which emphasized in pro et contra. The performance of national energy policy could be limited by the market instruments, the efficiency of the smart grid and perception of innovations in the energy sectors, institutional development in general. Thus, the paper aimed to indicate the impact of green innovations on sustainable development and the country's energy efficiency for 2000-2019. The authors used economic and mathematical modelling. The Ordinary Least Square Model was used for the integral assessment of energy efficiency policy. The authors analysed nine sub-indicators from four Sustainable development goals (Affordable and Clean Energy, Decent Work and Economic Growth, Responsible Consumption and Production, Combating Climate Change) and the indicator which characterized the innovation costs of industrial enterprises in the energy sector in Ukraine. The methodological instrument for checking the hypothesis and empirical justification was software stats models Python 3.6.11. Due to the seven rounds of optimisation, the authors developed significant functioning. Considering to the finding of Ordinary Least Square Modelling, the authors highlighted the determinants which influenced on the efficiency of energy policy: dependence on energy imports by-products, real GDP per capita, and final energy consumption. At the same time, the final energy consumption had less effect on the efficiency of energy policy and demonstrated the negative relationships with energy efficiency. The results of the models were verified using RESET and Jarque-Bera tests and confirmed the correctness of the proposed model.

Keywords: energy policy, sustainable development goals, green innovations, energy efficiency.

Cite as: Kolosok, S., Pimonenko, T., Yevdokymova, A., Hajiyev, N. O., Palienko, M., \& Prasol, L. (2020). Energy Efficiency Policy: Impact of Green Innovations. Marketing and Management of Innovations, 4, 50-60. http://doi.org/10.21272/mmi.2020.4-04 
S., Kolosok, T., Pimonenko, A., Yevdokymova, N. O., Hajiyev, M., Palienko, L., Prasol. Energy Efficiency Policy: Impact of Green Innovations

Introduction. Over the last decade, European energy policy has undergone radical changes. The effects of global crises, especially in the environmental and energy sectors, have caused an awareness of the need for sustainable development and energy stability (Dupont, 2016). Further environmental pollution will lead to global catastrophic results (Karintseva and Benetyte, 2018; Salihaj and Pryimenko, 2017). After the signing of the Paris Agreement, countries have made ambitious commitments to achieve climate and energy transformation of their economies (Gkonis et al., 2020). However, the implementation of such a policy does not always give unambiguous effects (Scholten et al., 2019; Ince, 2019; Reuter et al., 2019; Dupont, 2020). According to a study by Bertoldi and Mosconi (2020), the EU's energy efficiency policies have the best results in the industrial sector, average ones in the services sector. In the residential and transport sectors, the effect depended on government «policies on mitigation of energy demand».

The market-based instruments, the level of smart technology, and the perception of innovation in their energy sectors can limit the effectiveness of national policies. Therefore, when moving towards sustainable development and diffusion of green innovations, obstacles may arise in technical unpreparedness for change and imbalance of new energy systems (Bukarica and Tomsic, 2017). Transition economies mainly integrate renewable energy sources and energy-efficient technologies to achieve sustainable development goals (Dhakouani et al., 2019). And on the way to these changes, they may encounter significant resistance among existing energy market agents. A similar transformation is taking place in Ukraine. It is related to the Ukrainian government's need to comply with European integration and environmental initiatives, commitments to foreign partners (Makarenko and Sirkovska, 2017). However, do such changes improve the productivity of the energy sector in Ukraine? It is necessary to understand and assess the effectiveness of Ukraine's energy policy.

The aim of the article is to explain with the help of economic-mathematical model of energy efficiency factors in Ukraine for the last twenty years. This model is designed to answer the questions:

- How have SDG policy affected patterns of energy productivity in the Ukraine over the past twenty years?

- How effective are green innovations at raising of energy productivity?

The article contains five sections. The following section provides an overview of European energy efficiency policy and literature on green innovation and investment in Ukraine. The authors described the data and research methods in the third section. The results of modeling and testing the hypothesis are described in the fourth section. And the study concludes with the fifth section, which formed the main conclusions of the work.

Literature Review. Significant efforts have been made in Europe and the EU to harmonize European energy market regulation standards, measure energy efficiency and energy saving, and build a sustainable energy system (Kern et al., 2017). First of all, energy initiatives in the EU were aimed at overcoming dependence on energy imports. But they also aimed to reduce greenhouse gas emissions through the production and consumption of renewable energy (European Parliament and Council, 2006). The need to meet energy efficiency targets has been highlighted in numerous European Consul conclusions and has been one of the measurement targets in the Europe 2020 Strategy (2010). However, as early as 2011, there was an understanding that energy efficiency policies were not being followed and that the set goals were not being met. A more comprehensive approach was needed to implement energy efficiency initiatives. And in March 2011, the European Commission adopted a «Roadmap for moving to a competitive low carbon economy in 2050 » to reduce energy consumption by $20 \%$ through a cumulative contribution from EU member states (European Parliament and Council, 2012).

Realini et al. (2019) determine that the adoption of Directive 2012/27/EU was the trigger for updating energy efficiency legislation. However, the authors also emphasize that the renewal and implementation of energy efficiency policy is not homogeneous for all EU members, and therefore there are differences in national policies and in achieving energy efficiency goals. The same opinion is shared by Abeelen et al. 

Green Innovations

(2019). In general, the EU has both numerous promoters of the new energy efficiency policy and its uncompromising criticism.

In particular, Freire-González and Puig-Ventosa (2015), based on the Jevons paradox, question the possibility of achieving the goal of reducing energy consumption (and hence emissions of pollutants). As the introduction of energy efficient technologies, in this case, on the contrary, will encourage the use of cheaper technologies and expand product production (ie emissions into the environment will increase).

Brown (2015) emphasizes the need to update energy efficiency policies, but at the same time to maintain compliance with the requirements of energy efficiency programs, as failure to meet their goals can lead to a loss of public confidence in their reliability. In addition, there are opinions that in Europe the use of certain tools will not help achieve the relevant energy efficiency goals (Wiese et al., 2018).

However, among the works of scientists you can find a lot of evidence in support of energy efficiency initiatives. Collective work (Hartwig et al., 2017) argues that German energy efficiency policy has longterm macroeconomic effects. According to the authors, the positive impact on GDP and employment ranges from $0.88 \%$ to $3.38 \%$. You can find confirmation of these results in later works. Ringel et al. (2018) provide evidence that green energy policy in Germany affects GDP growth and job creation even in the short term, has lasting energy, environmental and socio-economic consequences from the implementation of energy efficiency reforms.

According to Pavlyk (2020a), there is cointegration between GDP, energy efficiency, the share of green investment and renewable energy sources in energy consumption. Improving the quality of regulatory activity and improving the rule of law leads to increased energy efficiency in the country (Shkarupa and Chasnyk, 2014; Pavlyk, 2020b).

From a historical retrospective, the role of the state in intensifying investment and innovation processes, qualitative transformation of ecological transformations is unconditional (Hrytsenko et al., 2018; Kolosok et al., 2018; Lupenko, 2018; Boichenko et al., 2019). However, local factors can also serve as a catalyst for the success of reforms (Morton et al., 2018). And to a large extent, their outcome depends on the level of cooperation and synergy between public authorities, private companies and public organizations (Kotenko et al., 2015; Yatsenko et al., 2019; Bertoldi and Mosconi, 2020).

Management processes that strengthen energy efficiency and investment can also stimulate energy innovation (Kim and Brown, 2019). The number of studies on green innovation has more than increased ninefold since 2008 and will only increase further (Panchenko et al., 2020). Promising in the field of green innovations are considered to be work on cloud computing and ERP-systems (Ragmani et al., 2018); smart grids (Barbier, 2020); energy efficiency, cycle economy (Sun et al., 2019).

The issue of green innovation and investment is also given due attention in Ukraine, especially in the field of energy efficiency. Many scientists are aware of the need to balance energy demand and justify the efficiency of tariffs to reduce heat losses and reduce energy consumption. In particular, for the transition to green energy production, researchers (Mentel et al., 2018; Labandeira et al., 2018; Kolosok et al., 2020) carry out regional differentiation of electricity tariffs in 13 regions of Ukraine, where the largest energy capacities are concentrated.

Analysis of the benefits of financing green investments to achieve sustainable development goals is performed by a group of scientists (Ibragimov, Lyeonov, et al., 2019; Ibragimov, Vasylieva, et al., 2019). They proved the existence of a relationship between the volume of green investment and the country's performance indicators towards achieving sustainable development goals. Consequently, the substantiation of the effectiveness of the state policy in the energy sphere should be based on indicators of sustainable development goals.

Methodology and research methods. Given the European integration direction of Ukraine, to assess the effectiveness of energy policy in Ukraine, the authors selected five EU sub-indicators for the model from the goal «Affordable and clean energy», 2 sub-indicators from the goal «Decent work and economic 
S., Kolosok, T., Pimonenko, A., Yevdokymova, N. O., Hajiyev, M., Palienko, L., Prasol. Energy Efficiency Policy: Impact of Green Innovations

growth», and one indicator from goals «Responsible consumption and production» and «Climate action», as well as an indicator of innovation costs of industrial enterprises in the energy sector (Table 1).

Table 1. The input variables of the model

\begin{tabular}{ccc}
\hline Indicator & Indicator description & Unit of measure \\
\hline SDG_07_10 & Primary energy consumption & Million tonnes of oil equivalent (TOE) \\
SDG_07_11 & Final energy consumption & Million tonnes of oil equivalent (TOE) \\
SDG_07_20 & Final energy consumption in households & Kilogram of oil equivalent (KGOE) \\
per capita & Energy productivity & Euro per kilogram of oil equivalent (KGOE) \\
SDG_07_30 & Percentage \\
SDG_07_50 & $\begin{array}{c}\text { Energy import dependency by products } \\
\text { Greenhouse gas emissions intensity of }\end{array}$ & Index, 2000=100 \\
SDG_13_20 & $\begin{array}{c}\text { energy consumption } \\
\text { Real GDP per capita }\end{array}$ & Euro per capita, chain linked volumes (2010) \\
SDG_08_10 & Percentage \\
SDG_08_11 & $\begin{array}{c}\text { Investment share of GDP by institutional } \\
\text { sectors }\end{array}$ & Euro per kilogram, chain linked volumes \\
SDG_12_20 & $\begin{array}{r}\text { Resource productivity and domestic } \\
\text { material consumption (DMC }\end{array}$ \\
INNOV & Innovation expenditure of industrial & Thousand UAH \\
& enterprises by areas of innovation (Code D & of NACE, Rev.2)
\end{tabular}

The source of statistical data for the input variables of the model was the State Statistics Service of Ukraine. Unfortunately, the Ukrainian statistical service does not publish statistics for sustainable development, which is completely identical to the EU statistical methodology. Therefore, the author team collected annual data from the Ukrainian statistics service for 2000-2019 and calculated them as indicators for the model in accordance with the Directive 2012/27/EU, Directive (EU) 2018/2002, Regulation (EC) No. 1099/2008, data descriptions of the Statistical Office of the European Union. Missing or unknown data for individual years for the model were filled using the moving average method.

Since the range of data varies considerably and contains different measures, it was decided to normalize them. It was necessary that each parameter contributed to a proportional contribution to the optimization result for the correct operation of the model. Min-max normalization was used to scale the data to a fixed range $[0,1](1)$ :

$$
x_{\text {norm it }}=\frac{x_{i t}-\min \left(x_{i t}\right)}{\max \left(x_{i t}\right)-\min \left(x_{i t}\right)}
$$

where $x_{i t}$ and $x_{n o r m}$ it are an original and the normalized value of the $i$-feature in in time $t, \max \left(x_{i t}\right)$ and $\min \left(X_{i t}\right)$ are the maximum and minimum values of the $i$-feature in in time $t$ in $x$ range.

After normalization of the data, histograms were constructed to select the best model for rapid evaluation of energy efficiency in Ukraine (Figure 1). According to the results obtained, it is impossible not to see differences in the distribution of data. Data are not centered, have several peaks and differences in averages (Table 2). The distribution of values with skewed to the left prevails, because their averages are less than the median. Analysis of dispersion statistics also shows some variations in values, from 0.270 (for the indicator of innovation costs) to 0.372 (for the indicator of primary energy consumption). 

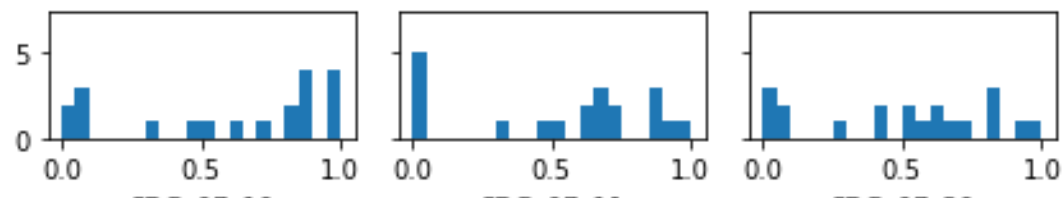

SDG_07_10

SDG_07_11

SDG_07_20
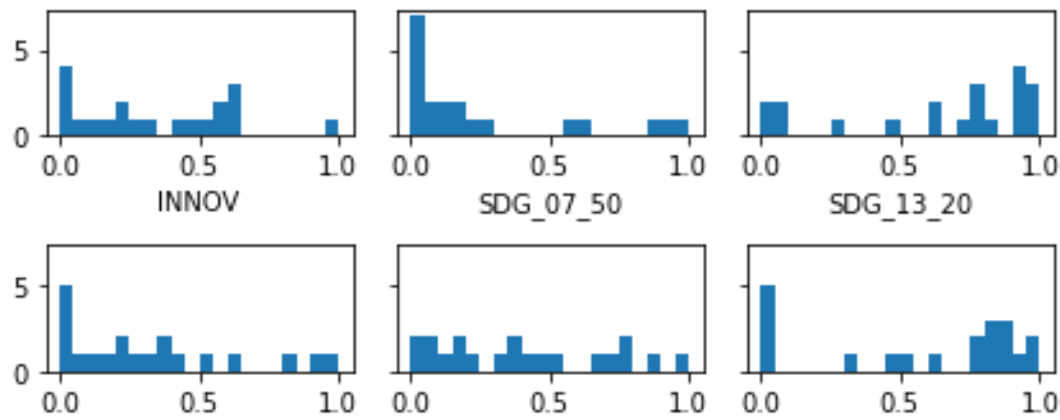

SDG_08_10

SDG_08_11

SDG_12_20

Figure 1. Histograms for the input variables of the model

Source: developed by the authors on the basis of (SSSU, 2020).

Table 2. The variables' descriptive statistics

\begin{tabular}{rrrrrrrrrrr} 
& SDG_07_10 & SDG_07_11 & SDG_07_20 & SDG_07_30 & SDG_07_50 & SDG_13_20 & SDG_08_10 & SDG_08_11 & SDG_12_20 & INNOV \\
\hline count & 20.000 & 20.000 & 20.000 & 20.000 & 20.000 & 20.000 & 20.000 & 20.000 & 20.000 & 20.000 \\
mean & 0.596 & 0.542 & 0.499 & 0.294 & 0.268 & 0.632 & 0.325 & 0.408 & 0.577 & 0.347 \\
std & 0.372 & 0.344 & 0.329 & 0.325 & 0.339 & 0.354 & 0.311 & 0.310 & 0.368 & 0.270 \\
$\min$ & 0.000 & 0.000 & 0.000 & 0.000 & 0.000 & 0.000 & 0.000 & 0.000 & 0.000 & 0.000 \\
$\mathbf{2 5 \%}$ & 0.256 & 0.252 & 0.216 & 0.042 & 0.023 & 0.436 & 0.069 & 0.149 & 0.251 & 0.131 \\
$50 \%$ & 0.762 & 0.656 & 0.545 & 0.181 & 0.130 & 0.760 & 0.240 & 0.373 & 0.753 & 0.302 \\
$75 \%$ & 0.880 & 0.771 & 0.748 & 0.398 & 0.357 & 0.909 & 0.443 & 0.675 & 0.867 & 0.574 \\
$\max$ & 1.000 & 1.000 & 1.000 & 1.000 & 1.000 & 1.000 & 1.000 & 1.000 & 1.000 & 1.000
\end{tabular}

Source: developed by the authors on the basis of (SSSU, 2020).

Given the results of descriptive statistics indicators was chosen the ordinary least squares model for evaluating the effects of the energy policy of Ukraine, which in general terms is as follows (2):

$$
y_{t}=X_{t} \beta_{i}+\varepsilon_{t}
$$

where the $p \times 1$ vector of dependent variable in time $t$, yt, is a linear combination of the $p \times q$ matrix of explanatory variables in time $t, X t, q \times 1$ vector of unknown coefficients $(i=1, . . q), \beta i$, and the $p \times 1$ vector of variables errors in time $t$, $\varepsilon t$.

The linear function of the input variables is presented below (3): 
S., Kolosok, T., Pimonenko, A., Yevdokymova, N. O., Hajiyev, M., Palienko, L., Prasol. Energy Efficiency Policy: Impact of Green Innovations

$S D G_{-} 07 \_30_{t}=\beta_{1}+\beta_{2} \cdot S D G_{-} 07 \_10_{t}+\beta_{3} \cdot S D G_{-} 07 \_11_{t}+\beta_{4} \cdot S D G_{-} 07 \_20_{t}+$ $\beta_{5} \cdot S D G_{-} 07-50_{t}+\beta_{6} \cdot S D G_{-} 13_{-} 20_{t}+\beta_{7} \cdot S D G_{-} 08_{-} 10_{t}+\beta_{8} \cdot S D G_{-} 08_{-} 11_{t}+$ $\beta_{9} \cdot S D G_{-} 12_{-} 20_{t}+\beta_{10} \cdot I N N O V_{t}+\varepsilon_{t}$

where energy productivity, SDG_07_30t, is a function of primary energy consumption, SDG_07_10t, final energy consumption, SDG_07_11t, final energy consumption in households per capita, SDG_07_20t, energy import dependency by products, SDG_07_50t, greenhouse gas emissions intensity of energy consumption, SDG_13_20t, real GDP per capita, SDG_08_10t, investment share of GDP by institutional sectors, SDG_08_11, resource productivity and domestic material consumption, SDG_12_20t, innovation expenditure of industrial enterprises, INNOV $t$, in time $t ; \beta_{1} . \beta_{10}$ - the coefficients of the OLS model; $\varepsilon_{t}-$ variables errors in time $t$.

According to the proposed model, the authors tested the question: «Does any of the $X_{t}$ variables help to explain energy productivity in the Ukraine over the past twenty years? » by substantiating hypotheses:

$$
\begin{aligned}
& H_{0}: \beta_{1}=\beta_{2}=. .=\beta_{10}=0 ; \\
& H_{a}: \exists \beta_{i} \neq 0, i=2, . ., 10 .
\end{aligned}
$$

To find variables that better describe the relationship to energy efficiency policy, a general-to-specific strategy was chosen. After obtaining significant values for all model variables, the regression coefficients were tested to prove the hypotheses using two tests: RESET test and Jarque-Bera test. The methodological tool for this research was the Python 3.6.11 package statsmodels, which was used to perform calculations and verification of the model.

Results. Prior to the simulation, the authors examined the relationship between the results of energy efficiency policy (an indicator of which is SDG_07_30) and endogenous indicators of a carbon-neutral economy using scatter plots.
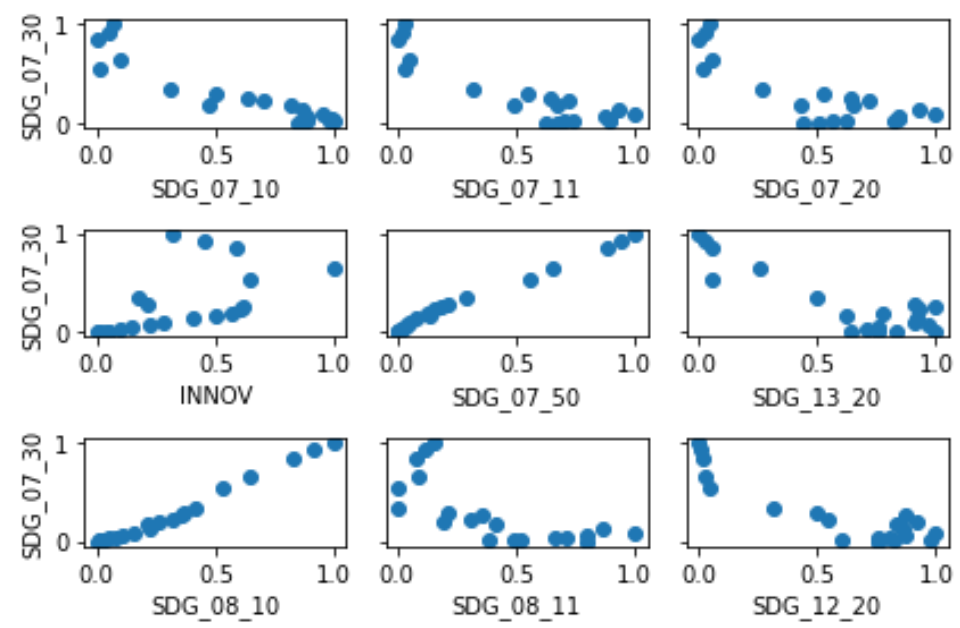

Figure 2. The scatter plots for the input variables of the model

Source: developed by the authors on the basis of (SSSU, 2020). 

Green Innovations

As shown in Figure 2, there is a strong positive linear relationship between energy efficiency and two of the nine indices.

These are «Energy import dependency by products» (SDG_07_50) and "Real GDP per capita» (SDG_08_10). The energy efficiency indicator can integrally measure the effectiveness of state regulatory interventions in the energy sector and is an indicator of the success or failure of energy reforms. In this case, according to the presented data, such a connection may indicate the coverage of energy needs with the growth of real GDP production due to net imports (net imports) of energy in the country. It may indicate some overstatement of tariffs for energy resources in Ukraine compared to the tariffs of neighboring countries. As for the costs of innovation in the energy sector, this index will not allow a linear description of the dependence, as there are outlier points (outlier points) in the area of increasing innovation costs.

Table 3 presents the results of OLS modeling for energy efficiency functions and selected endogenous indicators. Using a general-to-specific strategy, seven rounds of optimization were performed. The search ended when significant values were obtained for all model variables $p$-value (with the level of significance $a=0.05 \%)$. According to the results of OLS modeling, the indicator of energy policy efficiency in Ukraine is influenced by such variables as: «Energy import dependency by products» (SDG_07_50), «Real GDP per capita» (SDG_08_10), and «Final energy consumption» (SDG_07_11). Estimation of the last variable has a much smaller effect on the regression results, and shows a negative relationship with the energy efficiency index.

Table 3. The results of the OLS regression modelling

\begin{tabular}{|c|c|c|c|c|c|c|c|}
\hline & Model1 & Model2 & Model3 & Model4 & Model5 & Model6 & Model7 \\
\hline SDG_07_10 & $\begin{array}{l}0.0035 \\
(0.0130)\end{array}$ & $\begin{array}{l}0.0042 \\
(0.0080)\end{array}$ & & & & & \\
\hline SDG_07_11 & $\begin{array}{l}-0.0449 \\
(0.0582)\end{array}$ & $\begin{array}{l}-0.0480 \\
(0.0356)\end{array}$ & $\begin{array}{l}-0.0357 \\
(0.0261)\end{array}$ & $\begin{array}{l}-0.0185 * * * \\
(0.0035)\end{array}$ & $\begin{array}{l}-0.0183 * * * \\
(0.0033)\end{array}$ & $\begin{array}{l}-\theta .0171 * * * \\
(\theta .003 \theta)\end{array}$ & $\begin{array}{l}-0.0152 * * * \\
(0.0025)\end{array}$ \\
\hline SDG_07_20 & $\begin{array}{l}0.0202 \\
(0.0379)\end{array}$ & $\begin{array}{l}0.0220 \\
(0.0266)\end{array}$ & $\begin{array}{l}0.0144 \\
(0.0217)\end{array}$ & & & & \\
\hline SDG_07_50 & $\begin{array}{l}\theta .5269 * * * \\
(0.0169)\end{array}$ & $\begin{array}{l}\theta .5261 * * * \\
(0.0123)\end{array}$ & $\begin{array}{l}\theta .5277^{* * *} \\
(\theta .0115)\end{array}$ & $\begin{array}{l}\theta .5238 * * * \\
(\theta .0097)\end{array}$ & $\begin{array}{l}0.5246 * * * \\
(0.0090)\end{array}$ & $\begin{array}{l}0.5184 * * * \\
(0.0065)\end{array}$ & $\begin{array}{l}0.5167 * * * \\
(0.0064)\end{array}$ \\
\hline SDG_13_20 & $\begin{array}{l}0.0044 \\
(0.0044)\end{array}$ & $\begin{array}{l}0.0045 \\
(0.0040)\end{array}$ & $\begin{array}{l}0.0044 \\
(0.0039)\end{array}$ & $\begin{array}{l}0.0033 \\
(0.0035)\end{array}$ & $\begin{array}{l}0.0034 \\
(0.0033)\end{array}$ & & \\
\hline SDG_08_10 & $\begin{array}{l}\theta .4622 * * * \\
(\theta .0152)\end{array}$ & $\begin{array}{l}0.4626 * * * \\
(0.0136)\end{array}$ & $\begin{array}{l}0.462 \theta^{* * * *} \\
(\theta .0131)\end{array}$ & $\begin{array}{l}0.4686 * * * \\
(0.0084)\end{array}$ & $\begin{array}{l}0.4676 * * * \\
(0.0074)\end{array}$ & $\begin{array}{l}0.4722 * * * \\
(0.0058)\end{array}$ & $\begin{array}{l}0.4726 * * * \\
(0.0059)\end{array}$ \\
\hline SDG_08_11 & $\begin{array}{l}-0.0004 \\
(0.0050)\end{array}$ & & & & & & \\
\hline SDG_12_20 & $\begin{array}{l}0.0031 \\
(0.0037)\end{array}$ & $\begin{array}{l}0.0030 \\
(0.0033)\end{array}$ & $\begin{array}{l}0.0035 \\
(0.0030)\end{array}$ & $\begin{array}{l}0.0032 \\
(0.0029)\end{array}$ & $\begin{array}{l}0.0031 \\
(0.0028)\end{array}$ & $\begin{array}{l}0.0030 \\
(0.0028)\end{array}$ & \\
\hline Intercept & $\begin{array}{l}0.0112 \\
(0.0079)\end{array}$ & $\begin{array}{l}0.0116 * \\
(0.0057)\end{array}$ & $\begin{array}{l}0.0106 * \\
(0.0052)\end{array}$ & $\begin{array}{l}0.0077^{* *} \\
(0.0029)\end{array}$ & $\begin{array}{l}0.0076 * * \\
(0.0027)\end{array}$ & $\begin{array}{l}0.0092 * * * \\
(0.0022)\end{array}$ & $\begin{array}{l}0.0103 * * * \\
(\theta .002 \theta)\end{array}$ \\
\hline INNOV & $\begin{array}{l}-0.0022 \\
(0.0038)\end{array}$ & $\begin{array}{l}-0.0024 \\
(0.0031)\end{array}$ & $\begin{array}{l}-0.002 \theta \\
(0.0029)\end{array}$ & $\begin{array}{l}-0.0005 \\
(0.0019)\end{array}$ & & & \\
\hline R-squared & 1.0000 & 1.0000 & 1.0000 & 1.0000 & 1.0000 & 1.0000 & 1.0000 \\
\hline$R$-squared $A$ & 1.0000 & 1.0000 & 1.0000 & 1.0000 & 1.0000 & 1.0000 & 1.0000 \\
\hline
\end{tabular}

Standard errors in parentheses.

* $\mathrm{p}<.1, * * \mathrm{p}<.05, * * * \mathrm{p}<.01$

Source: developed by the authors on the basis of (SSSU, 2020).

The seventh-round optimization model is shown below (4):

$S D G_{-} 07 \_30_{t}=0.0103+0.0152 \cdot S D G_{-} 07 \_11_{t}+0.5167 \cdot S D G_{-} 07 \_50_{t}+$ $0.4726 \cdot S D G_{-} 08_{-} 10_{t}+\varepsilon_{t}$ 
S., Kolosok, T., Pimonenko, A., Yevdokymova, N. O., Hajiyev, M., Palienko, L., Prasol. Energy Efficiency Policy: Impact of Green Innovations

According to the simulation results, an increase in energy import dependence by products by $1 \%$ in Ukraine leads to an increase in energy productivity by $51.67 \%$ under other constant conditions.

The testing summary of the hypotheses of the seventh OLS model provided in Table 4 . Both, the RESET test and Jarque-Bera test, shows that the seventh model might be correctly specified. With a statistic of $\sim 1.199$ and a p-value of $\sim 0.274$ of the RESET test, and with a statistic of $\sim 0.011$ and a p-value of $\sim 0.994$ of the Jarque-Bera test, one may conclude that the seventh model is correctly specified (and the hypotheses $H_{0}$ rejected at the $5 \%$ level of significance).

Table 4. The testing summary of the hypotheses of the seventh OLS model

\begin{tabular}{cccc}
\hline Test name & Test statistic & p-value & Test result \\
\hline RESET & $\mathrm{F}=1.199$ & 0.274 & $H_{0}$ : Rejected \\
Jarque-Bera & $\mathrm{JB}=0.011$ & 0.994 & $H_{0}$ : Rejected
\end{tabular}

Source: developed by the authors on the basis of (SSSU, 2020).

Conclusions. The analysis of European energy efficiency policy issues is definitely necessary to understand the trajectory of the innovation movement of Ukraine's economy, the adaptation of green innovations and the strengthening of Ukraine's European integration aspirations. The goals of the energy market development strategy correspond to the harmonization of European standards of energy regulation, measurement of energy efficiency and energy saving, construction of a sustainable energy system. Funding for green innovation has its advantages in achieving the goals of sustainable development.

Using OLS modeling for energy efficiency functions and selected endogenous indicators, variables were investigated to explain the sources of energy efficiency in Ukraine over the last twenty years. According to the results of OLS modeling, the indicator of energy policy efficiency in Ukraine is influenced by such parameters as: «Energy import dependency by products» (SDG_07_50), «Real GDP per capita» (SDG_08_10), and «Final energy consumption» (SDG_07_11). Estimation of the last variable has a much smaller effect on the regression results, and shows a negative relationship with the energy efficiency index. The results of the model were verified using RESET and Jarque-Bera tests, and showed the correctness of the proposed model.

Author Contributions: conceptualization, T. P.; methodology, T. P.; software, S. K.; validation, S. K.; formal analysis, S. K.; investigation, S. K.; resources, A. Y.; data curation, N. H., A. Y.; writing-original draft preparation, A. Y., N. H.,; writing-review and editing, S. K.; visualization, S. K.; supervision, T. P., N. H.; project administration, T. P.; funding acquisition, S. K., T. P.

Funding: This research was funded by the grant from the National Research Foundation of Ukraine «Stochastic modelling of road map for harmonising national and European standards for energy market regulation in the transition to a circular and carbon-free economy» ID 2020.02/0231); the Ministry of Education and Science of Ukraine (the project No. 0119 U100766 «The optimization model of smart and secure energy grids building: an innovative technologies of enterprises and regions ecologisation »).

Acknowledgment. Authors appreciate the copyright holder: (C) State Statistics Service of Ukraine, SSSU, and to the source of the extracted data which is SSSU @ http://www.ukrstat.gov.ua/. 


\section{References}

Abeelen, C. J., Harmsen, R., \& Worrell, E. (2019). Disentangling industrial energy efficiency policy results in the Netherlands. Energy Efficiency, 12(5), 1313-1328. [Google Scholar] [CrossRef]

Barbier, E. B. (2020). Greening the post-pandemic recovery in the G20. Environmental and Resource Economics, 76(4), 685703. [Google Scholar] [CrossRef]

Bertoldi, P., \& Mosconi, R. (2020). Do energy efficiency policies save energy? A new approach based on energy policy indicators (in the EU member states). Energy Policy, 139. [Google Scholar] [CrossRef]

Boichenko, K. S., Tepliuk, M. A., Rekova, N. Y., Stashkevych, I. I., \& Morkunas, M. (2019). Management of fluctuation of financial and economic integrated development of innovative enterprise. Financial and credit activity: problems of theory and practice, 3(30), 62-69. [Google Scholar] [CrossRef]

Brown, M. (2015). Innovative energy-efficiency policies: An international review. Wiley Interdisciplinary Reviews: Energy and Environment, 4(1), 1-25. [Google Scholar] [CrossRef]

Bukarica, V., \& Tomsic, Ž. (2017). Energy efficiency policy evaluation by moving from techno-economic towards whole society perspective on energy efficiency market. Renewable and Sustainable Energy Reviews, 70, 968-975. [Google Scholar] [CrossRef]

Dhakouani, A., Znouda, E., \& Bouden, C. (2019). Impacts of energy efficiency policies on the integration of renewable energy. Energy Policy, 133, 110922. [Google Scholar] [CrossRef]

Dupont, C. (2016). Climate policy integration into EU energy policy: progress and prospects. London: Routledge. [Google Scholar]

Dupont, C. (2020). Defusing contested authority: EU energy efficiency policymaking. Journal of European Integration, 42(1), 95-110. [Google Scholar] [CrossRef]

European Parliament, \& Council (2012). Directive 2012/27/EU of the European Parliament and of the Council of 25 October 2012 on energy efficiency, amending Directives 2009/125/EC and 2010/30/EU and repealing Directives 2004/8/EC and 2006/32/EC (Text with EEA relevance; version: 26/10/2020). Retrieved from [Link]

European Parliament, \& Council. (2006). Directive 2006/32/EC of the European Parliament and of the Council of 5 April 2006 on energy end-use efficiency and energy services and repealing Council Directive 93/76/EEC (Text with EEA relevance; version: 11/12/2008). Retrieved from [Link]

Freire-González, J., \& Puig-Ventosa, I. (2015). Energy efficiency policies and the Jevons paradox. International Journal of Energy Economics and Policy, 5(1), 69. [Google Scholar]

Gkonis, N., Arsenopoulos, A., Stamatiou, A., \& Doukas, H. (2020). Multi-perspective design of energy efficiency policies under the framework of national energy and climate action plans. Energy Policy, 140, 111401. [Google Scholar] [CrossRef]

Hajiyev, N., Smolag, K., Abbasov, A., \& Prasolov, V. (2020). Energy War Strategies: The 21st Century Experience. Energies, 13(21), 5797. [Google Scholar] [CrossRef]

Hartwig, J., Kockat, J., Schade, W., \& Braungardt, S. (2017). The macroeconomic effects of ambitious energy efficiency policy in Germany-Combining bottom-up energy modelling with a non-equilibrium macroeconomic model. Energy, 124, 510-520. [Google Scholar] [CrossRef]

Hrytsenko, L. L., Roienko, V. V., \& Boiarko, I. M. (2018). Institutional background of the role of state in investment processes activation. Financial and credit activity: problems of theory and practice, 1(24), 338-344. [Google Scholar] [CrossRef]

Ibragimov, Z., Lyeonov, S., \& Pimonenko, T. (2019). Green investing for SDGS: EU experience for developing countries. Economic and Social Development: Book of Proceedings, 867-876. [Google Scholar]

Ibragimov, Z., Vasylieva, T., \& Lyulyov, O. (2019). The national economy competitiveness: effect of macroeconomic stability, renewable energy on economic growth. Economic and Social Development: Book of Proceedings, 877-886. [Google Scholar]

Ince, R. (2019). Local variations in implementing energy-efficiency policy: How third sector organisations influenced cities' responses to the green deal. Social policy review 31: Analysis and debate in social policy,197-220. Retrieved from [Link]

Karintseva, O., \& Benetyte, R. (2018). Estimation of Efficiency of State Regulation in Economic Restructuring Based on the Environmental Factor. SocioEconomic Challenges, 2(1), 91-102. [Google Scholar]

Kern, F., Kivimaa, P., \& Martiskainen, M. (2017). Policy packaging or policy patching? The development of complex energy efficiency policy mixes. Energy Research \& Social Science, 23, 11-25. [Google Scholar] [CrossRef]

Kim, Y. J., \& Brown, M. (2019). Impact of domestic energy-efficiency policies on foreign innovation: The case of lighting technologies. Energy Policy, 128, 539-552. [Google Scholar] [CrossRef]

Kolosok, S., Dementov, V., Korol, S., \& Panchenko, O. (2018). Public policy and international investment position in european integration of ukraine. Journal of Applied Economic Sciences, 13(8), 2375-2384. [Google Scholar]

Kolosok, S., Myroshnychenko, I., \& Zakharkina, L. (2020). Open data in electrical energy balancing of ukraine: Green deal and security aspects. Paper presented at the CEUR Workshop Proceedings, , 2732 270-281. Retrieved from [Link]

Kotenko, N. V., Serdiuk, S. G., \& Saltykova, A. V. (2015). Marketing management tools of funding and promotion services of non-governmental organizations. Marketing and Management of Innovations, (4), 20-33. Retrieved from [Link]

Labandeira, X., Labeaga, J. M., Linares, P., \& López-Otero, X. (2020). The impacts of energy efficiency policies: Metaanalysis. Energy Policy, 147, 111790. [Google Scholar] [CrossRef] 
S., Kolosok, T., Pimonenko, A., Yevdokymova, N. O., Hajiyev, M., Palienko, L., Prasol. Energy Efficiency Policy: Impact of Green Innovations

Lupenko, Y. O., Gutorov, A. O., \& Gutorov, O. I. (2018). Investment ensuring for development of integration relations in the agricultural sector of Ukrainian economy. Financial and credit activity: problems of theory and practice, 4(27), 381-389. [Google Scholar] [CrossRef]

Makarenko, I., \& Sirkovska, N. (2017). Transition to sustainability reporting: evidence from EU and Ukraine. Business Ethics and Leadership, 1(1), 16-24. [Google Scholar] [CrossRef]

Mentel, G., Vasilyeva, T., Samusevych, Y., \& Pryymenko, S. (2018). Regional differentiation of electricity prices: Socialequitable approach. International Journal of Environmental Technology and Management, 21(5-6), 354-372. [Google Scholar] [CrossRef]

Morton, C., Wilson, C., \& Anable, J. (2018). The diffusion of domestic energy efficiency policies: A spatial perspective. Energy Policy, 114, 77-88. [Google Scholar] [CrossRef]

Muradov, A.J., Hasanli, Y. H., \& Hajiyev, N.O. (2019). World Market Price of Oil: Impacting Factors and Forecasting. Springer International Publishing. XVI, 184. [Google Scholar] [CrossRef]

Panchenko, V., Harust, Yu., Us, Ya., Korobets, O., \& Pavlyk, V. (2020). Energy-Efficient Innovations: Marketing, Management and Law Supporting. Marketing and Management of Innovations, 1, 256-264. [Google Scholar] [CrossRef]

Pavlyk, V. (2020a). Assessment of green investment impact on the energy efficiency gap of the national economy. Financial Markets, Institutions and Risks, 4(1), 117-123. [Google Scholar] [CrossRef]

Pavlyk, V. (2020b). Institutional Determinants Of Assessing Energy Efficiency Gaps In The National Economy. SocioEconomic Challenges, 4(1), 122-128. [Google Scholar] [CrossRef]

Realini, A., Maggiore, S., Zagano, C., Oikonomou, V., \& Hofman, E. (2019). The need of harmonization in energy efficiency policies: Building a taxonomy for european industry. Paper presented at the Eceee Summer Study Proceedings, 643-648. Retrieved from [Link]

Reuter, M., Patel, M. K., \& Eichhammer, W. (2019). Applying ex post index decomposition analysis to final energy consumption for evaluating european energy efficiency policies and targets. Energy Efficiency, 12(5), 1329-1357. [Google Scholar] [CrossRef]

Salihaj, T., \& Pryimenko, S. (2017). Modification of the International Energy Agency Model (the IEA Model of Short-term Energy Security) for Assessing the Energy Security of Ukraine. SocioEconomic Challenges, 1(4), 95-103. [Google Scholar] [CrossRef]

Scholten, D., Criekemans, D., \& Van de Graaf, T. (2019). An energy transition amidst great power rivalry. Journal of International Affairs, 73(1), 195-204. [Google Scholar]

Shkarupa O. V., \& Chasnyk, O. M. (2014). Sustainable energy management in a "green» economy - the case of Ukraine. Marketing and Management of Innovations, 4, 192-199. [Google Scholar]f

SSSU. (2020). Statistical Information. The official website of the State Statistics Service of Ukraine. Retrieved from [Link]

Sun, H., Edziah, B. K., Sun, C., \& Kporsu, A. K. (2019). Institutional quality, green innovation and energy efficiency. Energy policy, 135, 111002. [Google Scholar] [CrossRef]

Wiese, C., Larsen, A., \& Pade, L. L. (2018). Interaction effects of energy efficiency policies: a review. Energy Efficiency, 11(8), 2137-2156. [Google Scholar] [CrossRef]

Yatsenko, O. M., Yatsenko, O. V., Nitsenko, V. S., Butova, D. V., \& Reva, O. V. (2019). Asymmetry of the development of the world agricultural market. Financial and credit activity: problems of theory and practice, 3(30), 423-434. [CrossRef]

Світлана Колосок, к.е.н., доцент, Сумський державний університет, Україна

Тетяна Пімоненко, д.е.н., доцент, Сумський державний університет, Україна

Альона Євдокимова, к.т.н., Сумський державний університет, Україна

Гаджиев Назим Озбей огли, Ph.D., Азербайджанський державний економічний університет, Азербайджан; Гарвардський університет, США

Максим Палієнко, Ph.D., Університет Інсурбіа, Iталія

Леся Прасол, підприємець, Китай

Ефективність енергетичної політики: вплив зелених інновацій

Європейська політика енергоефективності має ключову роль при формуванні нової моделі енергетичного ринку та вуглецево-нейтральної економіки в Україні. У цій статті виконано огляд актуальних дискурсивних питань на шляху до реалізації європейської політики енергетичної ефективності та зелених інновацій, наведені pro et contra таких реформ. Результативність національних політик може обмежуватися ринковими інструментами, рівнем забезпеченості розумними технологіями та сприйняттям інновацій у секторах енергетики, інституційного розвитку загалом. Тому основною метою дослідження було пояснення політики сталого розвитку та стимулювання зелених інновацій в Україн через економіко-математичне моделювання факторів енергоефективності за 2000-2019 роки. Для інтегрального оцінювання ефективності енергетичної політики в Україні авторами роботи була обрана OLS модель, що містить дев'ять субіндикаторів з чотирьох цілей сталого розвитку в ЄС (а саме: "Доступна та чиста енергія», «Гідна праця та економічне зростання», «Відповідальне споживання та виробництво» та «Боротьба зі зміною клімату»), а також показник інноваційних витрат промислових підприємств в енергетичній сфері в Україні. Методичним інструментарієм для проведення дослідження стало використання пакету statsmodels в Python 3.6.11, з допомогою якого були виконані 
S., Kolosok, T., Pimonenko, A., Yevdokymova, N. O., Hajiyev, M., Palienko, L., Prasol. Energy Efficiency Policy: Impact of Green Innovations

розрахунки та перевірка гіпотез моделі. При використанні стратегії розрахунків від загальної до конкретної моделі, була знайдена значима ффункція за сім раундів оптимізації. Biдnовідно до результатів OLS моделювання, на показник ефрективності енергетичної політики в Україні мають вплив такі змінні, як: «залежність від імпорту енергії за продуктами», «реальний ВВП на душу населення», та «кінцеве споживання енергії». Оцінка останньої змінної має значно менший ефект на результати регресії, та показує негативний зв'язок з показником енергоефективності. Результати моделей були перевірені за допомогою RESET та тестів Jarque-Веra, та показали коректність запропонованої моделі. Ключові слова: енергетична політика, цілі сталого розвитку, зелені інновації, енергоефективність

Manuscript received: 28.10 .2020

(C) The author(s) 2020. This article is published with open access at Sumy State University 